\title{
Effect of Protection of Soybean Meal Using Mahogany Leaf Extract in Ruminant Diet on Rumen Fermentation Products
}

\author{
Ifani M, Suhartati FM, Rimbawanto EA* \\ Faculty of Animal Science, Universitas Jenderal Soedirman \\ *E-mail: fk.aris.r@gmail.com \\ (received 11-07-2021; revised 08-10-2021; accepted 15-10-2021)
}

\begin{abstract}
ABSTRAK
Ifani M, Suhartati FM, Rimbawanto EA. 2021. Proteksi bungkil kedelai menggunakan ekstrak daun mahoni pada ransum ruminansia: pengaruhnya terhadap produk fermentasi rumen. JTV 26(3): 96-107. DOI: http://dx.doi.org/10.14334/jitv.v26i3.2829.

Penelitian bertujuan mengkaji pengaruh proteksi bungkil kedelai menggunakan ekstrak daun mahoni terhadap produk fermentasi rumen secara in vitro. Materi yang digunakan yaitu cairan rumen sapi, ransum basal terdiri dari konsentrat dan rumput gajah dengan rasio 60:40\%, dan daun mahoni. Penelitian dilaksanakan dalam tiga tahap yaitu ekstraksi mahoni, proteksi protein menggunakan ekstrak mahoni, dan tahap in vitro. Pengujian dilakukan secara in vitro dan mengunakan rancangan acak lengkap (RAL). Perlakuan terdiri 4 macam proteksi bungkil kedelai dengan konsentrasi tanin 0\% (P0); 1,5\% (P1); 3\% (P2); dan 4,5\% (P3). Data yang diperoleh dianalisis dengan analisis variansi dan diuji menggunakan orthogonal polinomial. Hasil penelitian menunjukan bahwa penambahan bungkil kedelai terproteksi ekstrak daun mahoni berpengaruh secara kubik terhadap VFA parsial, gas metan dan protein terlarut pasca rumen, berpengaruh secara kuadratik terhadap protozoa, serta berpengaruh secara linear terhadap $\mathrm{N}_{-} \mathrm{NH}_{3}$, SPM, dan RUDP. Pemberian ekstra daun mahoni taraf 1,5\% menghasilkan produk fermentasi yang tidak berbeda dengan kontrol, sedangakan pemberian taraf 3\% mendapatkan produk fermentasi tertinggi. Pemberian ekstak daun mahoni taraf 4,5\% menghasilkan SPM, dan RUDP tertinggi namun terjadi penunurunan pada protein terlarut yang menunjukan terjadinya over proteksi. Penambahan ekstrak daun mahoni taraf 3\% secara efektif mampu meningkatan produk fermentasi rumen, RUDP, dan protein terlarut tanpa mengganggu aktivitas bakteri rumen.
\end{abstract}

Kata Kunci: Mikroba, Protein, Rumen, Tanin

ABSTRACT

Ifani M, Suhartati FM, Rimbawanto EA. 2021 Protection of soybean meal using mahogany leaf extract in ruminant ration against rumen fermentation products. JITV 26(3): 96-107. DOI: http://dx.doi.org/10.14334/jitv.v26i3.2829.

The study was aimed to examine effect of protecting soybean meal using mahogany leaf extract on rumen fermentation products in vitro. The material used was cow rumen fluid, basal ration consisting of concentrate and elephant grass with a ratio of 60:40\%, and mahogany leaves. The research was carried out in three stages: mahogany extraction, protein protection using mahogany extract, and in vitro stages. The test was conducted in vitro based on a completely randomized design (CRD). The treatments consisted of 4 kinds of soybean meal protection with $0 \%$ tannin concentration (T0); $1.5 \%$ (T1); 3\% (T2); and 4.5\% (T3). Data obtained were analyzed by analysis of variance and tested using orthogonal polynomials. Results showed that addition of protected soybean meal with mahogany leaf extract had a cubical effect on partial VFA, methane gas and post-rumen dissolved protein, a quadratic effect on protozoa, and a linear effect on $\mathrm{N}-\mathrm{NH}_{3}, \mathrm{SPM}$, and RUDP. Giving extra mahogany leaves at a level of $1.5 \%$ produced a fermented product that was not different from the control while giving a level of $3 \%$ got the highest fermentation product. Giving mahogany leaf extract at a level of $4.5 \%$ resulted in the highest SPM, and RUDP but there was a decrease in soluble protein, which indicated the occurrence of overprotection. The addition of $3 \%$ mahogany leaf extract effectively increased rumen fermentation products, RUDP, and soluble protein without disturbing the activity of rumen bacteria.

Key Words: Microbes, Protein, Rumen, Tannins

\section{INTRODUCTION}

Soybean meal is a source of high-quality feed protein with a crude protein content of $49 \%$. Waldi et al. (2017) showed that soybean meal has a high in vitro solubility (60-80\%) so that it is quickly degraded in the rumen and within 48 hours it's protein degradation reached 24,149 $\mathrm{gN} /$ hour and was indicated by high levels of ammonia (12.97-14.42 mM). Soybean meal protein that is resistant to degradation in the rumen ranges from $22-53 \%$, while the digestibility of the rumen-resistent protein in the small intestine reaches 86-100\% (Arisya et al. 2019). The high level of protein degradation of soybean meal in the rumen causes soybean meal te need to be protected to reduce its degradability so that it can be used more efficiently.

Protein protection is commonly done by heating, adding formaldehyde, and using polyphenol compounds 
in plants such as tannins. Soybean meal protection using formaldehyde has a weakness. It can inhibit microbial activity in the rumen because formaldehyde dissolves and enters the rumen fluid (Suhartanto et al. 2014), while protein protection by heating makes protein difficult to be digested (Mayangsari et al., 2013). The digestibility of crude protein of soybean meal without protection, protection by heating, and protection with formaldehyde resulted in different digestibility, namely the highest protein digestibility of soybean meal protected by heating which was $96.9 \%$, followed by digestibility of soybean meal. Without protection was $96.4 \%$, and the lowest protein digestibility was protection with formaldehyde at $66.3 \%$ (Stern, et al., 2006).

Protein protection using condensed tannins is an alternative that can be used as a protein protection agent because it has the best efficiency level compared to protein protection using heating or formaldehyde. Condensed tannins have the potential to protect proteins from microbial degradation in the rumen (Prayitno et al., 2018) so that they can increase the amount of protein available to the host, while hydrolyzed tannins in excess amounts have the potential to poison livestock. The binding of the tannin-protein complex occurs at $\mathrm{pH}$ 3.5-7.0 and will separate at $\mathrm{pH}<3.5$ (Min and Solaiman 2018). The $\mathrm{pH}$ value corresponds to the $\mathrm{pH}$ in the abomasum. Separated tannin-protein complex bonds in the abomasum can increase protein in the intestine. This has been proven by Cahyani et al. (2012) who reported that the protein protection treatment of soybean flour using mangrove leaf tannins was able to reduce fermentability due to the formation of a tanninprotein complex. (Rimbawanto et al. 2015) stated that the use of calliandra condensed tannins in trash fish increased total protein digestibility in vitro.

The process of protein digestion depends on the separation of the tannin-protein complex in the abomasum because the bonds of the tannin-protein complex cannot wholly release each other, it is related to the different tannins and protein structures (Díaz Carrasco et al. 2017). Yusiati et al., (2018) found that mahogany leaves had a total tannin content of 11.9 $\mathrm{mg} / 100 \mathrm{mg} \mathrm{DM}$, consisting of condensed tannins $9.241 \pm 0.02 \mathrm{mg} / 100 \mathrm{mg} \mathrm{DM}$ and hydrolyzed tannins of $2.707 \pm 0.06 \mathrm{mg} / 100 \mathrm{mg}$ DM. The ability of the tannin to bind protein reaches $1,217 \mathrm{mg} \mathrm{BSA} / \mathrm{mg}$ leaf $\mathrm{DM}$, so that mahogany leaves have the potential to be used as a source of condensed tannins in protein protection for ruminant feed.

The high tannin content in mahogany leaves is expected to increase the effectiveness of soybean meal protein protection. In addition, when viewed from the availability, mahogany leaves are still widely available in the surrounding environment, but not many have been used. The use of mahogany leaves as a protein feed protection agent can increase the usefulness of this plant. Research on mahogany leaves as a source of tannins has not been done much, and the research is only limited to knowing the potential of mahogany leaves as goat feed ingredients. Therefore, this study aimed to examine the effect of soybean meal protected by mahogany leaf extract on the production of partial VFA (acetate, propionate, and butyrate), methane gas, protozoa, N-NH3, microbial protein synthesis, RUDP, and post-rumen protein solubility in vitro.

\section{MATERIALS AND METHODS}

The material used in this in vitro experiment was rumen fluid from three beef cattle taken from the Bantaruni Slaughterhouse (RPH), Kembaran District, Banyumas Regency, immediately after the cattle were slaughtered. The rumen was opened using scissors, then the contents was taken and put in two pieces of cheesecloth, then squeezed. The squeezed liquid was then accommodated through a funnel into an empty thermos previously filled with hot water to maintain the temperature in the thermos between $39-40{ }^{\circ} \mathrm{C}$. The tested rations was concentrate and forage with a ratio of 60:40 DM. The protected soybean meal was given as additional feed at $2 \% \mathrm{DM}$ of the total concentrate. The concentrate comprised of $20 \%$ DM coconut cake, $50 \%$ DM cassava, and 30\% DM polar. The composition of the feed is shown in Table 1. Proximate analysis of feed ingredients was carried out using the AOAC (2005) method to determine the nutrient content of each. Dry matter levels were obtained by heating $2 \mathrm{~g} \mathrm{DM}$ of samples at $105{ }^{\circ} \mathrm{C}$ for 8 hours or until the sample weight was stable. Ash levels were obtained by heating $2 \mathrm{~g}$ DM of samples at $600{ }^{\circ} \mathrm{C}$ for 12 hours. The protein content of the feed ingredients was obtained by distilling $0.1 \mathrm{~g}$ DM of sample, and the result of the distillation was then titrated with $\mathrm{HCl}$ solution. The fat content of feed ingredients was obtained by extracting $2 \mathrm{~g}$ DM of legume samples in soxhlet with ether as solvent. The crude fiber content of feed ingredients was obtained by washing $1 \mathrm{~g}$ DM of legume samples with several chemical solutions such as $\mathrm{H} 2 \mathrm{SO} 4, \mathrm{NaOH}$, acetone, and aquadest.

The crude extract of mahogany leaves comes from old mahogany leaves from a seven-year-old mahogany tree planted in the Faculty campus environment; General Sudirman University Livestock, with andosol type soil media and an average plant environmental temperature of $27{ }^{\circ} \mathrm{C}$ and humidity of $92-93 \%$. Mahogany leaves before extraction were heated at a temperature of $60 \mathrm{oC}$, finely ground with a 200 mesh sieve. The ability of condensed tannins to bind BSA was used as the basis for determining the level of condensed tannins in the treatment. The level of condensed tannins given is below the optimum, 
Table 1. Nutrient Composition of Feed Ingredients

\begin{tabular}{lccccc}
\hline \hline Feed & Dry Matter (\%) & Ash (\%) & Crude Protein(\%) & Crude Fat (\%) & Crude Fiber (\%) \\
\hline Elephant grass & 23.74 & 15.73 & 6.62 & 4.2 & 12.44 \\
Coconut meal & 86.00 & 13.01 & 21.52 & 24.58 & 14.46 \\
Onggok & 85.34 & 12.93 & 2.23 & 8.13 & 15.89 \\
Pollard & 85.55 & 13.37 & 12.51 & 9.79 & 14.71 \\
Soybean meal & 87.34 & 11.20 & 38.92 & 21.65 \\
\hline & & Nutrient Compositions of Concentrate & \\
\hline Concentrate & 85.54 & 12.37 & 13.34 & 6.2 & 17.9 \\
\hline \multicolumn{7}{c}{ Nutrient Composition of Diet } \\
\hline
\end{tabular}

optimum, and above optimum levels. The mahogany leaves used contained a total phenol of $15,32 \mathrm{mg} / 100$ $\mathrm{mg} \mathrm{BP}$, a total non-tannin phenol $2.05 \mathrm{mg} / 100 \mathrm{mg}$ BP and a total tannin content of $13.27 \mathrm{mg} / 100 \mathrm{mg} \mathrm{BP}$ consisting of condensed tannins $10.03 \mathrm{mg} / 100 \mathrm{mg}$ DM and hydrolyzed tannins $3.24 \mathrm{mg} / 100 \mathrm{mg}$ DM. The ability of mahogany tannins to bind BSA optimally was $5.93 \mathrm{mg} \mathrm{BSA} / 100 \mathrm{mg}$ DM mahogany leaves.

In vitro research was carried out at the Laboratory of Nutrition and Animal Feed Sciences, Fapet, Unsoed. Partial VFA analysis (acetic, propionic, and butyric acids) and methane gas was analysed using a set of gas chromatography. $\mathrm{N}_{-} \mathrm{NH}_{3}$ and microbial protein synthesis was measured by a spectrophotometer with an oxidizing solution, $\mathrm{HClO}_{4} 70 \%, \mathrm{NH}_{4} \mathrm{H}_{2} \mathrm{PO}_{4} 0.0285 \mathrm{M}$ $\mathrm{pH} 2, \mathrm{AgNO}_{3} 0.4, \mathrm{HCl} 0.5 \mathrm{~N}$. Dissolved protein and RUDPwas determined using oven, digestion flask and concentrated sulfuric acid scale, selenium catalyst, $40 \%$ $\mathrm{NaOH}, 3 \% \mathrm{H}_{3} \mathrm{BO}_{3}$, indicator methyl red and $0.1 \mathrm{~N} \mathrm{HCl}$.

The treatment consisted of 4 of tannins concentration levels to protect soybean meal namely of $0 ; 1.5 ; 3$; and $4.5 \%$ (Table 2). The experimental method applied was completely randomized design with oneway classification. Each treatment was replicated six times so that there were 24 experimental units. The data obtained were tabulated and then analyzed using analysis of variance. If the treatment has a significant effect on the response variable, it is further tested using orthogonal polynomials.

This study was carried out in three stages: the preparation stage, the rumen fluid incubation stage, and the measurement stage. The preparation stage includes the extraction of mahogany leaves. Extraction of mahogany leaves was carried out according to Rimbawanto et al. (2015) method and determination of total tannin in mahogany leaves based on Makkar (2003). The addition of tannins into soybean meal was done by spraying mahogany leaf extract using a sprayer into soybean meal until homogeneously mixed and then dried at room temperature. The second stage is the incubation stage. The incubation stage consists of anaerobic incubation and aerobic incubation, according to Tilley \& Terry (1963). The third stage was measurement phase consisted of measuring the concentration of partial VFA (acetate, propionate, butyrate), methane gas, concentration of $\mathrm{N}-\mathrm{NH} 3$, protozoa, and protein solubility.

The variables measured in this study were partial VFA concentrations (acetate, propionate, butyrate) which were measured using a gas chromatography technique following the method of Filipek and Dvorax (2009); Methane gas is calculated using the formula of Orskov (1996); Concentration of N-NH3 using the hypochlorite staining method (Weatherburn 1967); Microbial protein synthesis was measured using the method proposed by Zinn \& Owens, (1986); Protozoa population using methyl green formaline staining method which was calculated using a microscope according to Ogimoto \& Imai (1981); RUDP was calculated as \% RUDP $=100-\% \mathrm{CP}$ degradation (Chumpawadee et al., 2005); and Post-rumen crude protein digestibility or protein solubility (in vitro) was tested by looking at the sensitivity of the feed to the pepsin enzyme in an acidic environment (Calsamiglia and Stern 1995).

Mahogany leaves contain 10,03 mg/100 mg DM condensed tannins, and the ability of mahogany to bind protein reaches $1.217 \mathrm{mg} \mathrm{BSA} / \mathrm{mg} \mathrm{DM}$ (Yusiati et al. 2018). Crude protein of soybean meal reached $38,90 \%$ or equivalent to $389 \mathrm{mg}$ of $\mathrm{CF}$, so it was found that every $1 \mathrm{mg}$ of condensed tannins in mahogany leaves could bind $336.89 \mathrm{mg}$ of protein or every 1 gram DM of soybean meal could be bound with condensed tannins of $3 \%$. The provision of condensed tannins was calculated based on the ability of mahogany leaf condensed tannins to bind to pure protein, the varying 
levels of soybean meal protein degradation became the basis for giving mahogany leaf condensed tannins in several different levels.

This study was aimed to evaluate the condensed tannins of mahogany leaves in binding soybean meal protein, so as to determine the optimal level of protein protection. Soybean meal has various levels of degradation in the rumen reaching $50-80 \%$ so that the level of tannin protection is varied, namely $0 ; 1.5 ; 3$; and $4.5 \%$ were expected to determine the optimal concentration to protect soybean meal without disturbing rumen microbial activity and increasing postrumen total protein availability.

\section{RESULTS AND DISCUSSION}

Average yield of rumen fermentation products of rations added with the protected soybean meal is shown in Table 2. The average concentration of acetic acid in the study ranged from $28.01 \pm 2.1 \mathrm{mM}$ to $32.22 \pm 6.59 \mathrm{mM}$. Results of the analysis of variance (Appendix 3) showed that the addition of mahogany leaf extract with different levels had a very significant effect $(\mathrm{P}<0.01)$ on the production of acetic acid

The orthogonal polynomial test (Appendix 4) shows that the addition of Mintai extract has a cubic effect on the concentration of acetic acid with the equation $\mathrm{Y}=$ $39.63-13.19 \mathrm{X}+9.89 \mathrm{X} 2-1.51 \mathrm{X} 3$ (Figure 1) with a coefficient of determination $\left(\mathrm{r}^{2}\right)=0.51$ and the correlation coefficient $(r)=0.71$. Based on the resulting coefficient of determination, the equation can predict the effect of adding protected soybean meal with mahogany leaf extract to acetate with an accuracy of $51 \%$. Then $49 \%$ is influenced by factors outside the treatment.

Figure 1 shows that the addition of mahogany leaf extract initially decreased $5 \%$ acetic acid production from the control to $28.01 \mathrm{mM}$ at the $1.5 \%$ level of administration of mahogany leaf extract, then increased by $26 \%$ to $38.11 \mathrm{mM}$ at the level of $3 \%$ administration, but decreased again by $15 \%$ to $32.22 \mathrm{mM}$ at the level of $4.5 \%$ administration. It shows that the addition of tannin extract to soybean meal affects acetic acid production, with the lowest point at $\mathrm{T} 1(0.75 ; 24.70)$ and the highest point at T2 $(3.5 ; 39.56)$. A decrease at the level of $4.5 \%$ resulted in a higher acetic acid product than the level of $1.5 \%$, and this indicates that the provision of condensed tannin levels at the level of $3-4.5 \%$ creates a stable rumen environment so that it does not interfere with the activity of rumen bacteria. Based on the DMRT test, the decrease in acetic acid production at a level of $1.5 \%$ was not significantly different from the control. The low level of mahogany leaf tannins used in this treatment caused the fermentative power of carbohydrates in the rumen to have no significant effect on acetic acid production. Nuraliah and Purnomoadi (2015) stated that low levels of tannins in soybean meal in the ration had not affected the fermentation process in the rumen. The same fiber content also caused an

Table 2. Average of Partial VFA (Acetic acid, Propionic, acid and Butyric acids), Methane production, Protozoa number, N-NH3 concentration, and SPM of Protected Soybean Meal Extract Coarse Tannin Condensed Mahogany Leaves in Ration

\begin{tabular}{|c|c|c|c|c|c|}
\hline \multirow{2}{*}{ Parameter } & \multicolumn{4}{|c|}{ Treatment } & \multirow{2}{*}{ Significance } \\
\hline & T0 & $\mathrm{T} 1$ & $\mathrm{~T} 2$ & $\mathrm{~T} 3$ & \\
\hline \multicolumn{6}{|l|}{ VFA } \\
\hline Acetic acid (mM) & $29,67 \pm 0,64^{\mathrm{a}}$ & $28,01 \pm 2,1^{\mathrm{a}}$ & $38,11 \pm 4,11^{\mathrm{b}}$ & $32,22 \pm 6,59^{\mathrm{a}}$ & .002 \\
\hline Propionic acid (mM) & $8,40 \pm 0,55^{\mathrm{a}}$ & $7,69 \pm 0,57^{\mathrm{a}}$ & $10,59 \pm 0,54^{\mathrm{b}}$ & $8,77 \pm 1,61^{\text {a }}$ & .001 \\
\hline Butyric acid (mM) & $3,54 \pm 0,24^{\mathrm{a}}$ & $3,62 \pm 0,31^{\mathrm{a}}$ & $4,31 \pm 0,23^{\mathrm{b}}$ & $3,75 \pm 0,36^{\mathrm{a}}$ & .002 \\
\hline $\mathrm{C} 2: \mathrm{C} 3$ ratio & $3,54 \pm 0,2$ & $3,46 \pm 0,3$ & $3,59 \pm 0,3$ & $3,66 \pm 0,1$ & .756 \\
\hline EKH & $73,41 \%$ & $73,70 \%$ & $73,34 \%$ & $73,19 \%$ & 670 \\
\hline Methane $(\mathrm{MJ} / \mathrm{H})$ & $14,50 \pm 0,31^{\mathrm{a}}$ & $14,2 \pm 0,88^{\mathrm{a}}$ & $19,40 \pm 0,58^{\mathrm{b}}$ & $16,13 \pm 2,73^{\mathrm{a}}$ & .000 \\
\hline Protozoa $\left(\times 10^{5} \mathrm{sel} / \mathrm{ml}\right)$ & $5,85 \pm 0,4^{\mathrm{c}}$ & $4,14 \pm 0,5^{\mathrm{b}}$ & $2,79 \pm 0,6^{\mathrm{a}}$ & $2,51 \pm 0,4^{\mathrm{a}}$ & .000 \\
\hline $\mathrm{N}-\mathrm{NH}_{3}(\mathrm{mg} / \mathrm{dl})$ & $8,09 \pm 0,37^{\mathrm{a}}$ & $8,64 \pm 0,21^{\mathrm{b}}$ & $8,64 \pm 0,21^{\mathrm{b}}$ & $9,21 \pm 0,42^{\mathrm{c}}$ & .000 \\
\hline $\mathrm{SPM}(\mathrm{mg} / 100 \mathrm{ml})$ & $966,53 \pm 13,85^{\text {a }}$ & $977,8 \pm 13,5^{\text {a }}$ & $1006,53 \pm 15,5^{\mathrm{a}}$ & $1206,63 \pm 26,3^{b}$ & .000 \\
\hline RUDP (\%) & $12,94 \pm 0,96^{\mathrm{a}}$ & $15,19 \pm 0,04^{\mathrm{b}}$ & $16,50 \pm 0,73^{\mathrm{C}}$ & $17,61 \pm 0,97^{\mathrm{D}}$ & .008 \\
\hline Dissolved Protein (mg/g) & $35,20 \pm 1,9^{b}$ & $35,83 \pm 2,9^{\mathrm{a}}$ & $42,06 \pm 2,43^{\mathrm{b}}$ & $28,13 \pm 1,06^{\mathrm{c}}$ & .000 \\
\hline
\end{tabular}




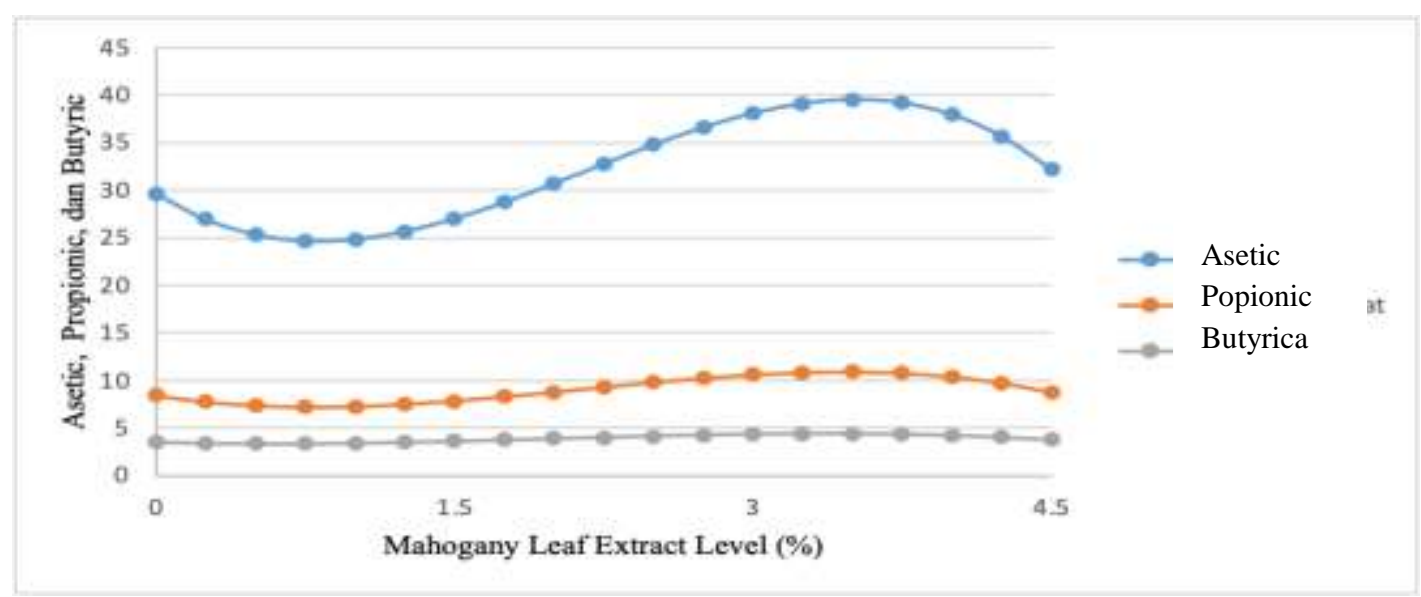

Figure 1. The Relationship between the Addition of Protected Soybean Meal from Mahogany Leaf Extract and Partial VFA (Acetic acid, Propionic acid, and Butyric acid)

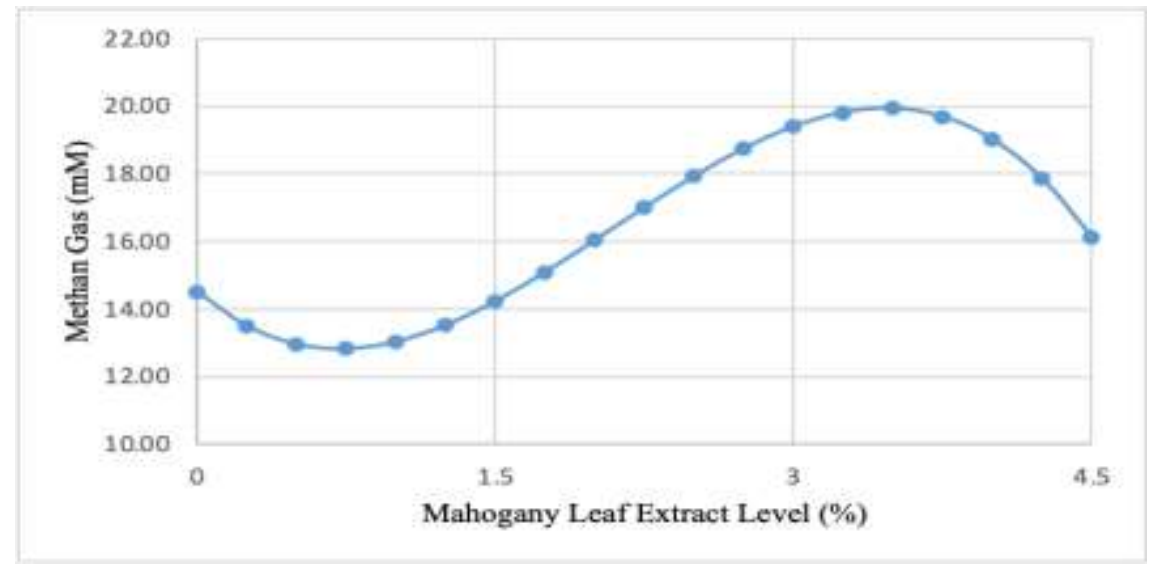

Figure 2. Effect of Addition of Protected Soybean Meal from Mahogany Leaf Extract on Methane Gas

insignificant difference in the percentages. Qori'ah et al., (2016) stated that acetic acid is the primary end product produced from fiber feed ingredients

The increase in acetic acid production at the $3 \%$ level illustrates that the mahogany leaf tannins do not interfere with the activity of cellulolytic bacteria, increasing acetic acid production. Tan et al. (2011) reported that the addition of condensed tannins in Quebracho leaves at a level of 1-2\% did not interfere with the activity of cellulolytic bacteria. Several factors that affect the concentration of acetic acid include microbial population, rumen $\mathrm{pH}$, and feed fermentability. The high concentration of acetic acid is related to the rumen $\mathrm{pH}$, which is in a balanced state so that the rumen microbes can work well in the fermentation process. Rindawati et al. (2019) stated that mahogany plants have secondary compounds, including flavonoid compounds, alkaloids, phenolics, saponins, and tannins. Alkaloid content in the alkaline mahogany leaf extract is thought to maintain the $\mathrm{pH}$ balance of the rumen. The higher acetic acid production compared to the control showed that the addition of mahogany leaf extract was considered to keep the rumen $\mathrm{pH}$ stable.
Propionic acid is the primary glucogenic fatty acid produced in the digestion of carbohydrates by ruminants. The lowest mean value of propionic acid was $7.69 \mathrm{mM}$ at the $1.5 \%$ mahogany leaf extract level, and the highest was $19.59 \mathrm{mM}$ at the $3 \%$ level (Table 2 ). The results of the analysis of variance (Appendix 3) showed that the provision of protected soybean meal with mahogany extract had a very significant effect $(\mathrm{P}<0.01)$ on the production of propionic acid, and the orthogonal polynomial test (Appendix 4) showed that the result was cubic with the equation $\mathrm{Y}=8.40-3.26 \mathrm{X}$ $+2.51 \mathrm{X} 2-0.39 \mathrm{X} 3$ coefficient of determination $\left(\mathrm{R}^{2}\right)=$ 0.56 and correlation coefficient $(\mathrm{R})=0.75$ (Figure 2 ).

Propionic acid production has the same dynamics as acetic acid production, which is an $8 \%$ decrease from control to $28.01 \mathrm{mM}$ at $1.5 \%$ level of mahogany leaf extract, then an increase of $27 \%$ to $10.59 \mathrm{mM}$ at $3 \%$ level but decreased again by $17 \%$ to $8.77 \mathrm{mM}$ at $4.5 \%$ level (Figure 1) with the highest point of propionic acid at T1 $(0.75 ; 7.21)$ and the highest point at T2 $(3.5$; 10.92). The decrease in propionic acid product at the level of $1.5 \%$ was lower than the decrease at the level of $4.5 \%$. This situation shows that condensed tannins at a 
level of $3-4.5 \%$ can increase the production of acetic acid, but at $1.5 \%$ it does not increase the production of propionic acid, which indicates the condition does not interfere with rumen activity. Based on the DMRT test, the decrease at the $1.5 \%$ level was not significantly different from the control. It showed that the addition of mahogany leaf extract at the $1.5 \%$ level had not shown a significant effect because the level of mahogany leaf extract given was low.

The increase in propionic acid production at the level of $3 \%$ is due to the mahogany leaves also containing secondary metabolites such as saponins that are reactive to protozoa. At that level, the concentration of saponins was able to inhibit the growth of rumen protozoa. Hidayah (2016) stated that saponins can kill or lyse protozoa by forming complex bonds with sterols to interfere with protozoa development. The decrease in the population of protozoa causes an increase in the population of rumen bacteria, especially amylolytic bacteria, resulting in an increase in the product of propionic acid in the rumen. The content of treatment rations containing high carbohydrates also caused the increased production of propionic acid produced.

The production of acetic and butyric acid at the level of $4.5 \%$ mahogany leaf extract in the ratio decreased, this was due to the mahogany leaf extract that was given containing saponins and tannins as protozoan defaunation agents, increasing rumen bacterial population. The increase in microbial activity caused the use of VFA for the microbial protein synthesis process (SPM) to increase, as indicated by the highest production of SPM at the level of $4.5 \%$ (Table 2).

The percentage of butyrate is the lowest compared to acetic and propionic acids, but butyrate also has an essential role in providing carbon chains for microbial protein synthesis. The results showed that the average product of butyric acid ranged from $3.54 \pm 0.24$ (P0) to $3.75 \pm 0.36$ (P3) (Table 2). The analysis of variance showed that the addition of soybean meal with mahogany leaf extract had a significant effect on butyric acid production. The results of the orthogonal polynomial test for butyrate showed that the provision of protected soybean meal with mahogany extract showed a cubic effect with the equation $Y=3.54-0.55$ $\mathrm{X}+0.54 \mathrm{X} 2-0.09 \mathrm{X} 3$ with a coefficient of determination $\left(r^{2}\right)=0.51$ and the correlation coefficient $(\mathrm{r})=0.71$ which is shown in Figure 1 .

Based on Figure 1, butyric acid production increased to the level of $3 \%$ mahogany leaf extract but decreased at $4.5 \%$ level. A decrease in the level of $4.5 \%$ resulted in higher butyric acid production compared to the control. This situation indicated that the addition of mahogany extract to a level of $4.5 \%$ did not interfere with the activity of rumen bacteria. In comparison, a decrease to a level of $4.5 \%$ indicated the utilization of butyric acid for microbial protein synthesis as indicated by the highest SPM at a level of $4.5 \%$.
The ratio of acetic and propionic acids (C2/C3) in the protection of soybean meal with mahogany leaf extract ratio tends to increase compared to the control. However, the values are relatively the same ranging from 3.59 to 3.66 (Table 2). The provision of protected soybean meal with mahogany leaf extract had no significant effect $(\mathrm{P}>0.05)$ on the $\mathrm{C} 2 / \mathrm{C} 3$ ratio because acetic acid production was in line with the production of propionic acid. The results showed that acetic acid production was higher than propionic acid, which means that it is acetogenic. That is, the product of acetic acid rose higher than propionate. Acetogenic describes that the activity of cellulolytic bacteria is more dominant than amylolytic bacteria. Table 2 shows that the addition of protected soybean meal with mahogany leaf extract had no significant effect $(\mathrm{P}>0.05)$ on the conversion efficiency of hexose to VFA. The percentage of EFH tends to increase at $1.5 \%$ mahogany leaf extract of $73.70 \%$, while in control, level $3 \%$ and $4.5 \%$ produces EFH of $73.41 ; 73.43 ; 73,19 \%$. It shows that although the $1.5 \%$ level did not have the highest partial VFA production, it produced the best energy efficiency compared to other levels and did not interfere with rumen microbial activity as shown by the partial VFA production, which was not significantly different from the control.

Energy efficiency can be seen from methane gas production. The highest methane gas production is $3 \%$ mahogany leaf extract, and the lowest is at the $1.5 \%$ level (Table 2). Methane is a gas formed from the anaerobic fermentation process of feed ingredients in the rumen by methanogenic bacteria, reflecting the loss of feed energy (Mosoni et al. 2011). The results of the analysis of variance (appendix 3) showed that the addition of the protected soybean meal had a very significant effect $(\mathrm{P}>0.01)$ on the production of methane gas. Results of the orthogonal polynomial test show the effect in a cubical way with the equation $\mathrm{Y}=14.50-$ $5.08 \mathrm{X}+4.29 \mathrm{X} 2-0.68 \mathrm{X} 3$ with the coefficient of determination $\left(r^{2}\right)=0.66$ and the correlation coefficient $(\mathrm{r})=0.81$ (Figure 2).

Figure 2 shows that the highest methane gas production is at $\mathrm{T} 2(3.5 ; 19.93)$, and the lowest is at $\mathrm{T} 1(0.75 ; 18.82)$. The production of methane gas is directly proportional to the production of acetic acid. The production of methane gas is directly proportional to the production of acetic acid. Methane gas production decreased in addition of $1.5 \%$ mahogany leaf extract, but the test results showed that the decrease was not significant. The dynamics of methane gas production same as acetic acid production, which decreases at the level of $1.5 \%$, then increases at the level of $3 \%$ and decreases again at the level of $4.5 \%$. The high production of methane gas at the level of 3$4.5 \%$ indicates a less efficient use of energy shown by the low EKH compared to the level of $1.5 \%$. Based on Figure 2. the addition of mahogany leaf extract to the 
ration has not been able to reduce methane, the data is in line with the results of Jayanegara et al. (2018) which states that condensed tannins have not been able to reduce methane production. The formation of methane gas causes it to be formed by methanogenic bacteria using $\mathrm{H} 2$ obtained from acetic acid. Yanuartono et al. (2019) stated that methanogenic bacteria need $\mathrm{H}_{2}$ gas to create methane gas. The formation of acetate triggers the formation of $\mathrm{H}_{2}$ so that it will be utilized by methanogenic bacteria to be converted into $\mathrm{CH}_{4}$. The higher the acetic acid produced, the higher the methane gas produced. Hikmawan et al. (2019) reported in their research that methane gas production was positively correlated with acetic acid production.

Methanogenesis in the digestive system of animal rumen is one of the macromolecular fermentation reaction pathways that produces $\mathrm{CH}_{4}$ gas through $\mathrm{CO}_{2}$ reduction with hydrogen gas catalyzed by enzymes produced by methane bacteria. Methanogenic bacteria are often found living attached to the surface of the rumen protozoa to keep getting a constant supply of hydrogen. Still, not all methanogenic bacteria attach to the protozoa. Anggraeny et al. (2021) stated that methanogenic bacteria associated with ciliated protozoa are responsible for the process of methanogenesis in rumen fluid between $9-25 \%$.

Results of the analysis of variance (attachment 3) showed that the addition of protected soybean meal with mahogany leaf extract had a very significant effect $(\mathrm{P}>0.01)$, and the orthogonal polynomial test showed the impact in a quadratic manner with the equation $\mathrm{Y}=$ $5.88-1.47 \mathrm{X}+0.16 \mathrm{X} 2$ with a coefficient of determination $\left(\mathrm{r}^{2}\right)=0.85$ and a correlation coefficient $(\mathrm{r})=0.92$ (Figure 3 ). Figure 3 shows that the protozoa population decreased with the addition of mahogany leaf extract, which was given with the highest point at T0 $(0 ; 585)$ and the lowest point at T3 $(4.5 ; 250)$. The decrease in protozoa in each treatment was significant. This illustrates the presence of protozoa growth disorders due to the addition of protected soybean meal from mahogany leaf extract. Rindawati et al. (2019) stated that mahogany plants have secondary compounds, including flavonoid compounds, alkaloids, phenolics, saponins, and tannins.

Based on the calculation of the total phenol in the tested mahogany leaf extract, $34.71 \mathrm{mg} / 100 \mathrm{mg} \mathrm{DM}$, the high phenol content disrupted the protozoa population. Since tannins are phenolic compounds that are reactive with cell walls of microorganisms and extracellular enzymes produced by microorganisms. Yulistiani et al. (2011) stated that tannins could suppress the number of protozoa that are predators of bacteria and cause an increase in rumen degradation. The content of saponins in mahogany leaves is also thought to cause a decrease in the population of protozoa. Wahyuni et al. (2014) stated that saponins could lyse protozoa by forming complex bonds with sterols found on the surface of the protozoan membrane.

Protozoa have an essential role in maintaining rumen $\mathrm{pH}$. Protozoa can quickly utilize fermentable carbohydrates for their needs and provide the advantage of slowing down the conversion of fermentable carbohydrates to lactic acid by rumen bacteria to control $\mathrm{pH}$. The decrease in protozoa was marked by an increase in the product of propionic acid when compared to the control, a decrease usually followed by an increase in propionic acid in the production of acetic acid. Still, with the addition of protected soybean meal, the increase in propionic acid was followed by an increase in acetic acid. This shows that the addition of mahogany leaf extract was thought to maintain a stable rumen $\mathrm{pH}$. Alkaloid content in the alkaline mahogany leaf extract is believed to maintain the $\mathrm{pH}$ balance of the rumen. The high partial of VFA concentration is related to the rumen $\mathrm{pH}$, which is balanced so that the rumen microbes can work well in the fermentation process.

The fermentation process was also shown the increase in the concentration of $\mathrm{N}-\mathrm{NH}_{3}$ along with the addition of the protection level of soybean cake with mahogany leaf tannins. The concentration of $\mathrm{N}^{-\mathrm{NH}_{3}}$ is one indicator to determine the fermentability of feed protein, microbial activity, and rumen microbial population. The concentration of $\mathrm{N}-\mathrm{NH}_{3}$ describes the amount of feed protein that can be fermented in the rumen, and its value is strongly influenced by the ability of rumen microbes to degrade feed protein and whether or not feed protein is easily degraded (Susilo et al., 2019). Analysis of variance showed that the addition of the protected soybean meal in different levels had a very significant effect $(\mathrm{P}<0.01)$ on increasing the concentration of $\mathrm{N}-\mathrm{NH}_{3}$. The orthogonal polynomials test shows the influence linearly with the equation $\mathrm{Y}=$ $14.13+0.22 \mathrm{X}$ with a coefficient of determination $\left(\mathrm{r}^{2}\right)=$ 0.59 and a correlation coefficient $(r)=0.77$ (Figure 4).

Figure 4 shows increase concentration of $\mathrm{N}-\mathrm{NH}_{3}$ along with the addition of the concentration of mahogany leaf extract given with the highest production at T3 $(4.5 ; 15.21)$ and the lowest at T0 $(0$; 14.09). The content of the treatment ration used had a relatively high crude protein content, namely $13.49 \%$, and the concentrate composition containing coconut meal with a high level of degradability caused a high concentration of $\mathrm{N}-\mathrm{NH}_{3}$ produced. A decrease also followed the increase in the concentration of $\mathrm{N}-\mathrm{NH}_{3}$ in the protozoan population. The decreased protozoa population caused the population of rumen bacteria to increase, including proteolytic bacteria, as indicated by the increased rumen protein fermentation process. Herdian et al. (2014) stated that a decrease in the protozoa population would increase the availability of ammonia in the rumen. Based on the DMRT test, the concentration increase at the $3 \%$ level was not 
Ifani et al. Protection of soybean meal using mahogany leaf extract in ruminant ration against rumen fermentation products

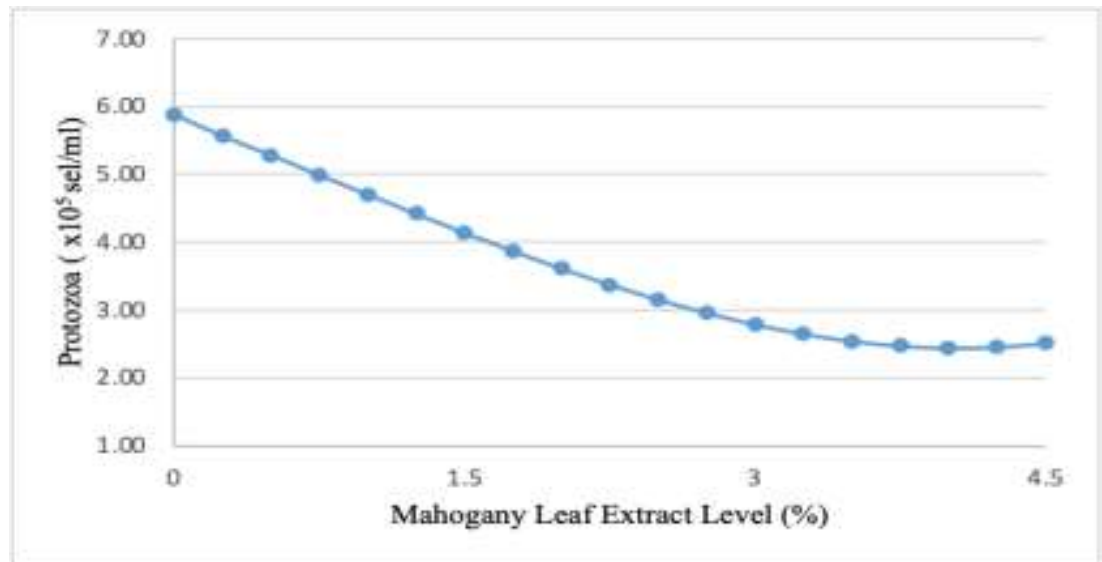

Figure 3. The Relationship between the Addition of Protected Soybean Meal from Mahogany Leaf Extract on the Protozoa Population

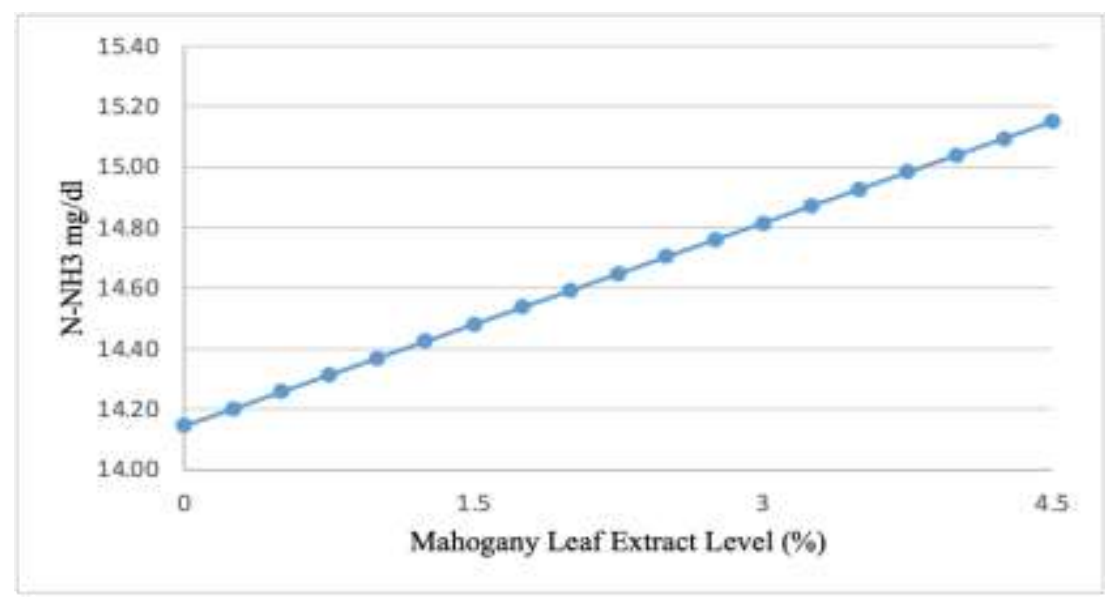

Figure 4. The relationship between the addition of protected soybean meal from mahogany leaf extract to N-NH3

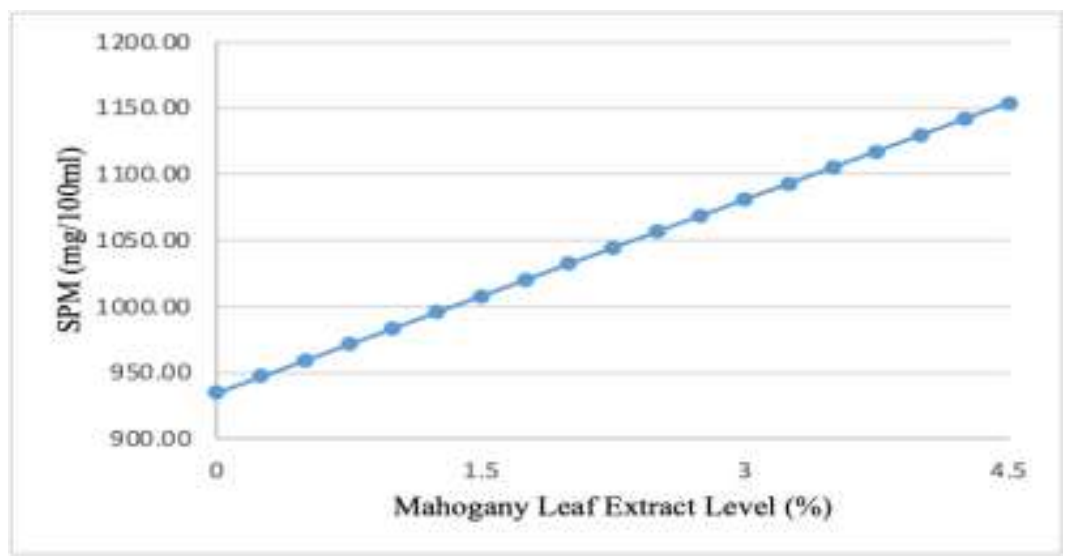

Figure 5. The Relationship between the Addition of Protected Soybean Meal from Mahogany Leaf Extract on SPM

significantly different from the $1.5 \%$ level. It showed that the $1.5 \%$ level effectively increased the $\mathrm{N}^{-\mathrm{NH}_{3}}$ concentration compared to the control

Concentration of $\mathrm{N}^{-\mathrm{NH}_{3}}$ is related to microbial protein synthesis because microbes in the rumen utilize $\mathrm{N}-\mathrm{NH}_{3}$ as the primary nitrogen source for microbial protein synthesis. Microbial protein synthesis will be optimal if there is a synchronization of the release time between the nitrogen source and the carbon skeleton in the rumen. The high and low concentration of microbial protein synthesis in each treatment was related to the availability of VFA and ammonia, which was influenced by the amount of mahogany leaf extract that protected soybean meal in each treatment. Results of 
analysis of variance showed that the addition of mahogany leaf extract had a very significant effect $(\mathrm{P}<0.01)$ on microbial protein synthesis, the results of the orthogonal polynomial test showed a linear influence with the equation $\mathrm{Y}=935+48.6 \mathrm{X}$ with a coefficient of determination $\left(\mathrm{r}^{2}\right)=0.46$ and the correlation coefficient $(r)=0.68$ (Figure 5).

Figure 5 shows that microbial protein synthesis (SPM) increased with increasing levels of mahogany leaf extract (Table 2). This increase was due to the addition of Mahogany leaf extract that make the rumen environment stable so that the activity of rumen bacteria increased. The decreased protozoa population causes an increase in bacterial rumen activity so that the feed fermentation process becomes optimal and can provide a nitrogen source and energy source for the microbial protein synthesis process. It is indicated by the availability of carbohydrate fermentation products (partial VFA) and protein $\left(\mathrm{N}-\mathrm{NH}_{3}\right)$. Qori'ah et al. (2016) stated that microbial protein synthesis could run optimally if there is a supply of nitrogen and organic matter in the rumen.

The composition of the treatment ratio had a high protein content of $13.4 \%$, so that it was able to provide ammonia for microbial protein synthesis. Protein in the balance indicates the availability of $\mathrm{N}$ for rumen microbes which help microbial growth and production of microbial synthesis in digesting nutrients. The increase in microbial protein synthesis followed by the rise in the concentration of $\mathrm{N}-\mathrm{NH}_{3}$ (Table 2) illustrates that the feed ingredients in the treatment have a high level of degradability so that the available concentration of $\mathrm{N}^{-\mathrm{NH}_{3}}$ is high even though it has been used for microbial protein synthesis. Suwandyastuti (2013) stated that microbial protein synthesis is influenced by sources of nitrogen intake, whether or not protein is quickly degraded, and the availability of $\mathrm{N}$ and energy sources.

The mean Rumen Undegradable Protein (RUDP) was $12.94 \pm 0.94$ (T0), $15.19 \pm 0.04$ (T1), 16.50 \pm 0.73 (T2), and 17.61 $\pm 0,97$ (T3) listed in Table 2. RUDP is a feed protein that is not degraded in the rumen, so it can directly undergo enzymatic digestion in the abomasum and intestine. The results of the analysis of variance showed that the addition of protected soybean meal with mahogany leaf extract in the ratio had a very significant effect $(\mathrm{P}<0.01)$ on RUDP, and the orthogonal polynomial test showed a linear regression effect with the equation $\mathrm{Y}=13.26+1.02 \mathrm{X}$ with a coefficient of determination $\left(\mathrm{r}^{2}\right)=0.83$ and correlation coefficient $(r)=0.91$ (Figure 6).

Figure 6 shows an increase in RUDP along with the addition of mahogany leaf extract, which was given with the lowest value at the control and the highest at the $4.5 \%$ level. This situation shows that increasing level of mahogany leaf extract given will increase the total protein that is not degraded in the rumen. (Yisehak et al. 2016) stated that the size of the protein that escapes degradation in the rumen is influenced by several factors, namely the solubility of the protein, the more excellent the solubility of a protein, the greater the degradation process.

The increase followed the increased content of RUDP in the rumen in the range of ammonia, and this indicates that the degradation of feed protein in the rumen is high. This illustrates that the tannin content in mahogany leaf extract can provide optimal conditions for rumen microbes to degrade feed so that the ammonia produced is high. Another condition that causes high ammonia production is that the treatment ratio contains high protein. The protein is degraded to ammonia and released quickly. The ammonia should be absorbed through the rumen, but there was no absorption by rumen because the study was carried out in vitro. The increasing percentage of RUDP indicates that condensed tannins in mahogany leaves can form complex bonds between condensed tannins and proteins that are resistant to rumen microbial degradation. The condensed tannin complex and protein bonds will be released after reaching the abomasum at a $\mathrm{pH}$ of less than 4 to increase the total post-rumen protein. This is because the complex bonds of condensed tannins and proteins will decompose at an acidic $\mathrm{pH}$, and proteins can be digested in the abomasum. Yusiati et al. (2018) stated that condensed tannins could increase protein that escapes rumen degradation due to its ability to bind protein at neutral $\mathrm{pH}$ conditions. Still, at acidic $\mathrm{pH}$ conditions such as in the abomasum, protein will be released to digested in the abomasum and intestine.

The effectiveness of the protected protein can be seen from the dissolved protein in the post-rumen or abomasum. The study showed that the lowest soluble protein value was in control, and the highest was at the $3 \%$ level (Table 2). The analysis of variance showed that the addition of protected soybean meal with mahogany leaf extract showed very significant results $(\mathrm{P}<0.01)$ for soluble protein. The results of the orthogonal polynomial test show a cubic regression 


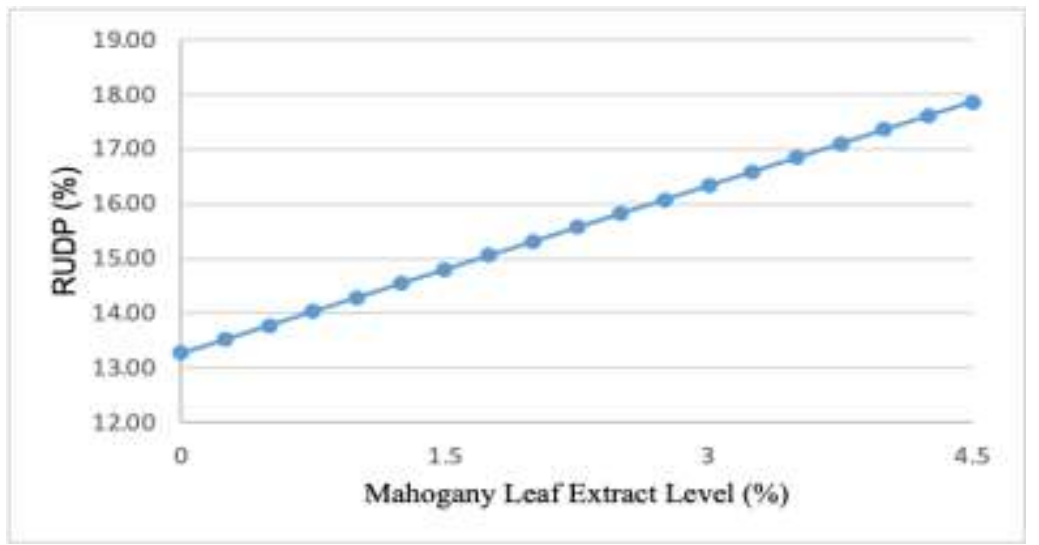

Figure 6. The relationship between the addition of protected soybean meal with mahogany leaf extract to RUDP

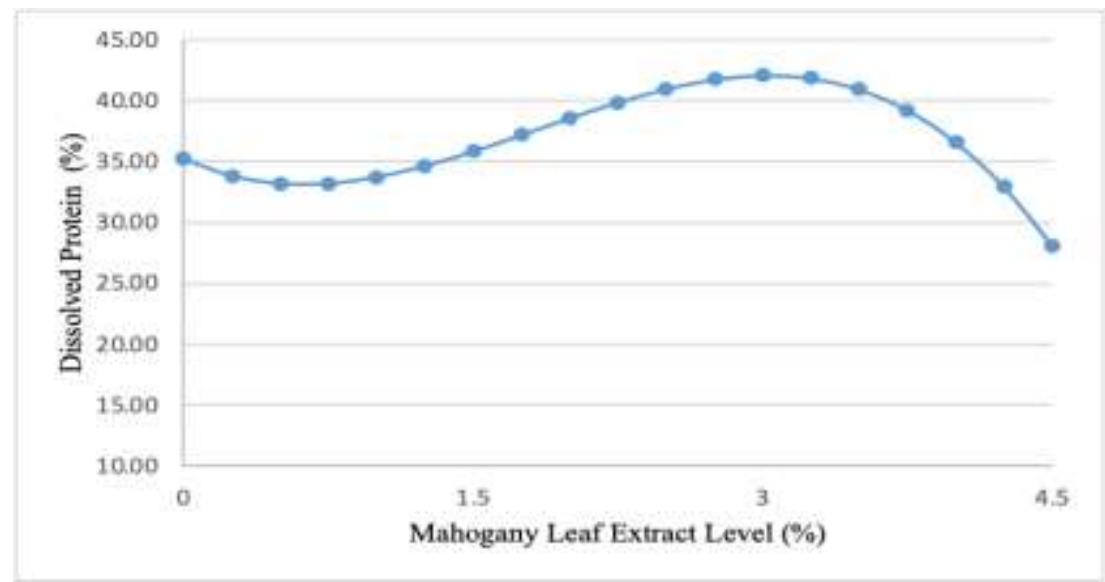

Figure 7. The Relationship between the Addition of Protected Soybean Meal from Mahogany Leaf Extract on Dissolved Protein

response with the equation $\mathrm{Y}=35.20-7.16 \mathrm{X}+6.96$ $\mathrm{X} 2-1.27 \mathrm{X} 3$ with a coefficient of determination $\left(\mathrm{r}^{2}\right)=$ 0.85 and a correlation coefficient $(r)=0,92$ (Figure 7).

Figure 7 shows that soluble protein experienced an insignificant decrease in the addition of $1.5 \%$ soybean meal extract, then increased to a level of $3 \%$ and decreased significantly again at a level of $4.5 \%$. The decrease in soluble protein at $4.5 \%$ level of mahogany leaf extract resulted in lower soluble protein than the control with the most insufficient production at T3 (4.5; $28.13)$ and the highest at T2 (3; 42.06). This situation shows that condensed tannins in mahogany leaves can form concentrated tannin bonds with feed protein, resulting in increased post-rumen soluble protein compared to controls. Based on the DMRT test, the total dissolved protein at the level of $1.5 \%$ was not significantly different from the control, it showed that the level of $1.5 \%$ had not had a significant effect, while at the level of $3 \%$, it showed the best results. The increase in soluble protein showed that the administration of mahogany leaf extract at a level of 3\% was able to increase total protein/amino acids, especially in the post-rumen without disturbing rumen microbial activity, as indicated by higher microbial protein synthesis than control and resulted in the best energy efficiency among other treatments. Rimbawanto et al. (2017) stated that the protection of soybean meal using condensed tannins in lamtoro leaves in vitro did not inhibit microbial protein synthesis in the rumen and increased the supply of postrumen microbial protein.

Soybean meal protection aims to increase the total soluble protein without disturbing the activity of rumen bacteria. At the level of $4.5 \%$, soluble protein decreased. This condition indicates that at the level of $4.5 \%$, there is overprotection. Overprotection is when the bond between protein and condensed tannins is too strong so that the solubility of pepsin- $\mathrm{HCl}$ becomes low. Giving at the level of $4.5 \%$ was not effective, seen from the rumen microbial activity indicated by a decrease in carbohydrate fermentation products (partial VFA). It showed that the condensed tannin level of $4.5 \%$ had begun to interfere with the activity of rumen bacteria.

High content of condensed tannins in mahogany leaves can increase the effectiveness of protein protection in soybean meals. In addition, when viewed from the availability, mahogany leaves are underutilized because mahogany is developed for 
industrial forest plantations, mahogany wood is mainly used as construction material. The use of mahogany leaves as a protein feed protection agent can increase the usefulness of this plant. The results of this study can be easily carried out by farmers because the addition of mahogany leaves as a source of condensed tannins does not need to go through extraction. In ruminants, the protection process of soybean meal can be done naturally through mechanical digestion in the mouth.

Noted: all the graphics are actually not necessary to present, since all information in the graphics have already been presented in Table 2 .

\section{CONCLUSION}

The addition of protected soybean meal by mahogany leaf extract at a level of $1.5 \%$ produced the best-rumen fermentation products. It was able to optimally increase RUDP and post-rumen soluble protein.

\section{REFERENCES}

Anggraeny Y N. et al. 2021. "Evaluation of the use of plant organic components and probiotics on ruminal characteristics and as a decrease of methane. IOP Conference Series: Earth and Environmental Science 648.

AOAC. 2005. "Official Methods of Analysis of AOAC International." AOAC.

Arisya, W, Ridwan R, Ridla M, Jayanegara A. 2019. Tannin Treatment for protecting feed protein degradation in the rumen in vitro. J Physics: Conf Series 1360: 10-15.

Cahyani RD, Nuswantara LK, Subrata A. 2012. Pengaruh Proteksi protein tepung kedelai dengan tanin daun bakau terhadap konsentrasi amonia, undegraded protein dan protein total secara in vitro. Anim Agric J. 1: 15966.

Calsamiglia S, Stern MD. 1995. "A Three-Step in Vitro Procedure for Estimating Intestinal Digestion of Protein in Ruminants. J Anim Sci. 73: 1459-65.

Chumpawadee S, Sommart K, Vongpralub T. 2005. Estimation of Rumen Undegradable Protein with In Situ Nylon Bag and In Vitro Enzymatic Technique in Tropical Concentrate Feedstuffs. Walailak J Sci Tech 2: 23-33.

Hikmawan D, Erwanto, Muhtarudin, Fathul F. 2019. Pengaruh substitusi rumput laut (Eucheuma cottonii) dalam pakan rumput gajah (Pennisetum purpureum) terhadap konsentrasi VFA parsial dan estimasi produksi gas metana secara in-vitro. Jurnal Riset dan Inovasi Peternakan. 3: 12-18. DOI: 10.23960/jrip.2019.3.1.1218.

CarrascoJMD, Cabral C, Redondo LM, Viso NDP,
Colombatto D, Farber MD, Miyakawa MEF. 2017. Impact of chestnut and quebracho tannins on rumen microbiota of Bovines. BioMed Res Int. 2017.

Rimbawanto EA, Suhermiyati S, Hartoyo B. 2017. Produk Fermentasi dan mikroba rumen domba lokal yang ransumnya disuplementasi by pass protein. Prosiding Seminar Teknologi dan Agribisnis Peternakan Seri V. 363- 367.

Filipek J, Dvorak R. 2009. Deterination of the volatile fatty acids content in the rumen luquid: comparison of gas chromatograpy and capillary isotachophoresis. Acta Vet Brno 78: 627-33.

Herdian H, Istiqomah L, Febrisantosa A, Setiabudi D. 2014. Pengaruh Penambahan daun Morinda citrifolia sebagai sumber saponin terhadap karakteristik fermentasi , defaunasi protozoa, produksi gas dan metana cairan rumen secara in vitro. JITV. 15: 99-104.

Hidayah N. 2016. Utilization of plant secondary metabolites compounds (tannin and saponin) to reduce methane emissions from ruminant livestock. WARTAZOA. 11: 89-98.

Jayanegara A, Ridla M, Laconi EB, Nahrowi N. 2018. Tannin as a Feed additive for mitigating enteric methane emission from livestock: meta-analysis from RUSITEC experiments. IOP Conference Series: Materials Science and Engineering. 434.

Makkar HPS. 2003. Quantification of Tannin in the Tree and Shrub Legumes: A Laboratory Manual. Dordrecht (ND): Kluwer Academic. p 112

Mayangsari NS, Subrata A, Christiyanto M. 2013. Pengaruh proteksi protein ampas kecap dengan tanin terhadap konsentrasi amonia, produksi protein total dan persentase rumen undegraded dietary protein secara in vitro. J Anim Agric. 2: 261-68.

Min BR, Solaiman S. 2018. Comparative aspects of plant tannins on digestive physiology, nutrition and microbial community changes in sheep and goats: A Review. J Anim Physiol Anim Nut. 102: 1181-93.

Mosoni P, Martin C, Forano E, Morgavi DP. 2011. Long-term defaunation increases the abundance of cellulolytic ruminococci and methanogens but does not affect the bacterial and methanogen diversity in the rumen of sheep. J Anim Sci. 89: 783-91.

Keiji O, Imai S. 1981. Atlas of Rumen Microbiology. Tokyo (JP) : Japan Scientific Societies press.

Orskov ER, Rayle M. 1996. Energy Nutrition in Ruminant. Amsterdam (NED): Elsevier Science Publisher.

Prayitno RS, Wahyono F, Pangestu E. 2018. Pengaruh suplementasi sumber protein hijauan leguminosa terhadap produksi amonia dan protein total ruminal secara in vitro. JPI. 20: 116

Qori'ah Al, Surono, Sutrisno. 2016. Sintesis protein mikroba dan aktivitas selulolitik akibat penambahan level zeolit sumber nitrogen slow release pada glukosa murni 
secara in vitro. Jurnal Ilmu-Ilmu Peternakan. 26: 1-7.

Rimbawanto EA, Yusiati LM, Baliarti E, Utomo R. 2015. Effect of condensed tannin of Leucaena and Calliandra leaves in protein trash fish silage on in vitro ruminal fermentation, microbial protein synthesis and digestibility. Anim Prod. 17: 83-91.

Rindawati N, Daniel, Saleh C. 2019. Uji fitokimia, uji toksisitas dan aktivitas antioksidan dari biji tumbuhan Mahoni (Swietenia mahagoni (L) Jacq). Jurnal Atomik. 4: 78-81.

Nuraliah S, Purnomoadi A, Nuswantara LK. 2015. Konsentrasi asam lemak terbang dan glukosa darah domba ekor tipis yang diberi bungkil kedelai terproteksi tanin. Jurnal Veteriner. 16: 448-56.

Stern MD, Bach A, Calsamiglia S. 2006. New Concepts in Protein Nutrition in Ruminants. Proceeding Annual Southwest Nutrition \& Management Conference. 897904.

Suhartanto B,Utomo R, Kustantinah, Budisatria IGS, Yusiati LM, Widyobroto BP. 2014. Pengaruh penambahan formaldehid pada pembuatan undegraded protein aktivitas mikrobia rumen secara in vitro. Buletin Peternakan. 38: 141-149.

Susilo,E, Nuswantara LK, Pangestu E. 2019. Evaluasi bahan pakan hasil samping industri pertanian berdasarkan parameter fermentabilitas ruminal secara in vitro. JSPI 14: $128-36$

Suwandyastuti SNO. 2013. Pengaruh nisbah energi-protein, nitrogen-sulfur dan kalsium-fosfor terhadap produk metabolisme rumen dan kecernaan substrat. Jurnal Agripet. 13: 1-6.

Tan HY, Sieo CC, Abdullah N, Liang JB, Huang XD, Ho YW. 2011. Effects of condensed tannins from leucaena on methane production, rumen fermentation and populations of methanogens and protozoa in vito. Anim
Feed Sci Technol. 169: 185-93.

Tilley JMA, Terry RA. 1963. A Two-stage technique for the in vitro digestion of forage crops. Grass and Forage Science. 18: 104-111. DOI: 10.1111/j.13652494.1963.tb00335.x

Wahyuni IMD, Muktiani A, Chirtianto M. 2014. Penentuan dosis tanin dan saponin untuk defaunasi dan peningkatan fermentabilitas pakan. Agric. 53: 1689-99.

Waldi L, Suryapratama W, Suhartati FM. 2017. Pengaruh Penggunaan Bungkil Kedelai dan Bungkil Kelapa dalam Ransum Berbasis Indeks Sinkronisasi Energi dan Protein Terhadap Sintesis Protein Mikroba Rumen Sapi Perah. JaLSPro. 1:1-12. DOI: 10.31002/jalspro.v1i1.446.

Weatherburn MW. 1967. Fenol-hypoclorite reaction for determination of ammonia. Anal Chem. 39: 971-74.

Yanuartono, Nururrozi A, Indarjulianto S, Purnamaningsih H. 2019. Peran protozoa pada pencernaan ruminansia dan dampak terhadap lingkungan. Ternak Tropika. 20: 1628.

Yisehak K, Kibrear Yoseph, Taye T, Lourenço MRA. 2016. Response to dietary tannin challenges in view of the browser/grazer dichotomy in an Ethiopian setting: Bonga Sheep versus Kaffa Goats. Trop Anim Health Prod. 48: 125-31. DOI: 10.1007/s11250-015-0931-3.

Yulistiani D, Mathius IW, Puastuti W. 2011. Bungkil Kedelai terproteksi tanin cairan batang pisang dalam pakan domba sedang tumbuh. JITV. 16: 33-40.

Yusiati LM, Kurniawati A, Hanim C, Anas MA. 2018. Protein Binding capacity of different forages tannin. IOP Conf. Series: Earth and Environmental Science. 119: 012007. DOI: $10.1088 / 1755-1315 / 119 / 1 / 012007$

Zinn RA, Owens FN. 1986. A rapid procedure for purine measurement and its use for estimating net ruminal protein synthesis. Canadian J Anim Sci. 66: 157-66. 